\title{
Anthropogenic Geoasset Exploration in Bukit Besi for Geotourism Development: A Preliminary Study
}

(Penjelajahan Geoaset Antropogen di Bukit Besi untuk Pembangunan Geopelancongan: Kajian Awalan)

\author{
MARILAH SARMAN*, NOR SHAHIDAH MOHD NAZER, KADDERI Md DESA, AZIMAH HuSin, \\ NORASIAH SULAIMAN \& AMIR HUZAIRY
}

\begin{abstract}
Geotourism is a responsible and sustainable type of tourism package development, equivalent to ecotourism, and other nature-based derivatives of tourism with deeper level considerations on local landscapes and the underlying geological foundation. The area was investigated from the perspective of tourism geoscience sub-discipline with a focus on nonextractive natural resources. Taking into consideration the beach alluvial plain, human community, the biophysical components and the mining artifacts, mineralization, geological formation, mining history and people lifestyle during the active mining period. Bukit Besi's rail transit system as example, with eleven stations, used to transport people, goods and ores between Bukit Besi and a coastal town of Dungun. Geology of Bukit Besi consist of dominance of shale, quartzite, limestone; intrusion rocks of granite and quartz vein, and metasediment rock. Iron mineralization occurs as a result of replacement in shale, limestone, granite and along the developed fractures. Further study relates the interconnection between iron mineralization and cultural of the residents. Mineralization had created the mining operation in Bukit Besi. History of mining process, life of Bukit Besi residents and railway is part of intrinsic information that make higher value of monument left in Bukit Besi in tourism context. Historical narration of the mining region goes beyond events related to human time frame but spans the geological history of the regions and the story of interactions between human and their environments. These form the basis for the creation of anthrobiogeoasset for regional planning of the region. Secondary utilization of the non-extractive natural resource should incorporate tourism and business components for sustainable geotourism package development of Bukit Besi, Malaysia
\end{abstract}

Keywords: Cultural; geoasset; geotourism; iron ore mine; mineralization

\section{ABSTRAK}

Geopelancongan adalah sejenis pembangunan pakej pelancongan yang bertanggungjawab dan mampan, setara dengan ekopelancongan dan pelancongan berasaskan alam semula jadi dengan pertimbangan tahap yang lebih mendalam terhadap landskap tempatan dan asas geologi yang mendasarinya. Kawasan ini dikaji daripada perspektif sub-disiplin geosains pelancongan dengan tumpuan kepada sumber alam bukan ekstraktif, dengan mengambil kira kawasan pantai, komuniti manusia, komponen biofizikal dan artifak perlombongan, permineralan, formasi batuan, sejarah perlombongan dan gaya hidup penduduk semasa tempoh perlombongan aktif. Sistem transit kereta Bukit Besi antaranya, dengan sebelas stesen, pernah digunakan untuk mengangkut orang, barang dan bijih di antara Bukit Besi dan Dungun. Geologi Bukit Besi terdiri daripada dominasi syal, kuarza, batu kapur; batu intrusi granit dan telerang kuarza dan batuan metasedimen. Pembentukan mineral besi adalah akibat penggantian syal, batu kapur dan granit di sepanjang rekahan yang terbentuk. Kajian lanjut menunjukkan hubung kait yang rapat antara pemineralan bijih besi dengan budaya penduduk. Pemineralan telah membentuk operasi perlombongan di Bukit Besi. Sejarah, proses perlombongan, kehidupan penduduk Bukit Besi dan kereta api adalah sebahagian daripada maklumat intrinsik yang memberikan nilai yang lebih tinggi kepada Bukit Besi dalam konteks pelancongan. Penceritaan sejarah kawasan perlombongan melampaui peristiwa yang berkaitan dengan kerangka masa manusia tetapi merangkumi sejarah geologi kawasan dan kisah interaksi antara manusia dan persekitaran mereka. Ini membentuk dasar untuk kewujudan antrobiogeoaset untuk perancangan wilayah di rantau ini. Penggunaan sekunder sumber semula jadi bukan ekstraktif harus menggabungkan komponen pelancongan dan perniagaan untuk pembangunan pakej geopelancongan yang mampan di Bukit Besi, Malaysia.

Kata kunci: Budaya; geoaset; geopelancongan; lombong bijih besi; pemineralan

\section{INTRODUCTION}

Tourism Geoscience is a field of specialization in geoscience education. It has been formalized as a part of the geoscience curriculum at Universiti Kebangsaan Malaysia for the exploration of anthrobiogeoasset (geoasset), a non-extractive class of natural resources for regional planning and tourism development. Bukit Besi was a well-known iron mining region in Malaysia from the early 
1920s until the mine was closed in 1973 (Anuar 1985). A geoscientific study has been conducted to identify and explore the geoasset of the study area based on geotourism concept. The concept of geotourism received geological community attention since late 80 s, ironically the concept has been diversified as early as 1872 when Yellowstone was established by the President of the USA as National Park. The establishment of Yellowstone National Park has gained long term economic profit through the use of undestructive resources concept. This concept is relatively new in Malaysia which started in 1997 along with the development of geoheritage concept (Ibrahim \& Hamzah 1993). The idea of developing tourism based on geological input is still not completely understood by most Malaysian and hence doubting its affectiveness as tourism attraction.

Although there are over 200 geosites of geoheritage values that are systematically identified in Malaysia, not all are suitable to be developed as geotourism localities (Mohd Shafeea \& Ibrahim 2004). Figure 1(a) shows how geoheritage and geotourism is overlap in terms of functionality. Therefore, tourism geosciences as a field in geology should also be developed in a systematic manner.

This paper will try to assess, plan and manage geoasset as the tourism capital. Figure 1(b) shows geoasset interconnection between the geology of an area, biotic systems of plants and animals that depend on geoscape foundation habitat and human culture. According to Kadderi $(2000,1995$, geoasset is a new class of resources in geotourism focusing on five major concepts which are: Intrinsic value concept, use of non-destructive resources concept, dynamic stability and ecosystem longevity, human habitat planning and management of environment foundation, and the concept of Touristic Development as an initiator to tourism industry.

\section{BUKIT BESI AS A CASE STUDY}

Bukit Besi has been chosen as the case study to perform these geoasset exploration for geotourism purposes. Bukit Besi is a remote area located in the state of Terengganu Darul Iman which situated $33 \mathrm{~km}$ from Dungun Town and $77 \mathrm{~km}$ from Kuala Terengganu. The mine is about $3 / 4$ mile wide and 2 miles long. The coordinate of Bukit Besi is $4^{\circ}$ $45^{\prime} \mathrm{N}$ and $103^{\circ} 10^{\prime}$ E (Jabatan Pemetaan Negara, 1968 \& 1969). Bukit Besi was once the largest producer of iron ore in the country (Duncan 1959). The presence of iron ore in this area has led to the opening of an advanced mining area that offers many job opportunities for local residents. Success and prosperity achieved by Bukit Besi has made this place and its surrounding area developed rapidly. Basic facilities were available and various infrastructures such as schools, markets, health centres, police stations, movie theatre and stadium were built for the residents' conveniences. The construction of a port in Dungun has also making Dungun town to develop as fast as Bukit Besi. The transportation system available in Bukit Besi was far ahead of the other town nearby. The construction of the railway commenced by Nippon Mining Company in 1929 has made the transportation of processed iron ore for export becomes easier and quickly. The railway service was not only served as a mean of transportation of iron to the port, but also used as public transport for residents to go to any nearby destinations.

\section{GEOLOGY}

Bukit Besi is located between the inconsistent contact area of Paleozoic sediment and granite rock (Jabatan Mineral dan Geosains Malaysia 2004). The Carboniferous sedimentary rocks consist of shale with small amounts of quartzite and limestone (Figure 2). The sediments received low metamorphism and folded during granite intrusion (Burton 1973). Granitic intrusives have caused thermal metamorphism of the rocks at the contact area. Sedimentary rocks near the contact area also changed and calc - silicate band Hornfels were formed (Anuar 1983). The variety of minerals such as quartz, hornblende and minor epidote, diopside, some sericite, garnet, sfen, casiterite and magnetite can be found in this calc - silicate Hornfels (Bean \& Hill 1969). No pegmatitic dikes and aplite reported found in this area, but there is the discovery of quartz veins cutting granite and sedimentary bodies found in Bukit Besi. Sedimentary rocks in Bukit Besi consists of shale, quartzite and limestone These sediments have a minimum thickness of 1000 feet and most are found exposed on the surface (Hill 1962).

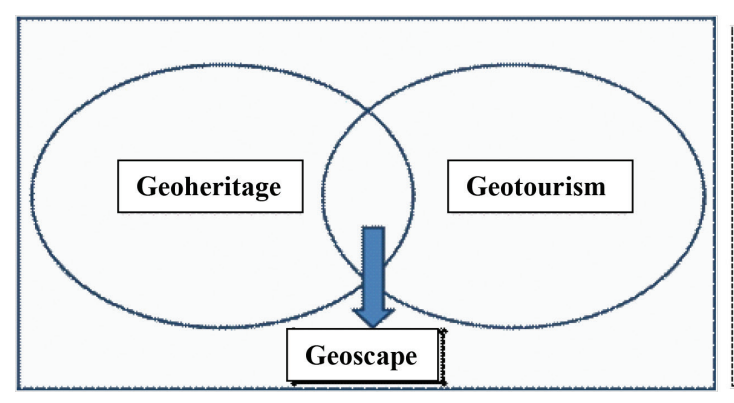

(a)

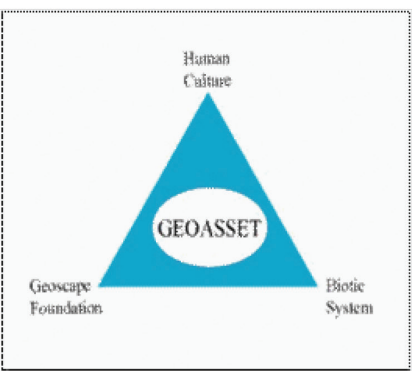

(b)

FIGURE 1. (a) Overlap between geoheritage and geotourism will produce potential geoscape as geoasset for development of tourism geoscience and (b) Geoscape interrelationships between culture, human and biotic systems 


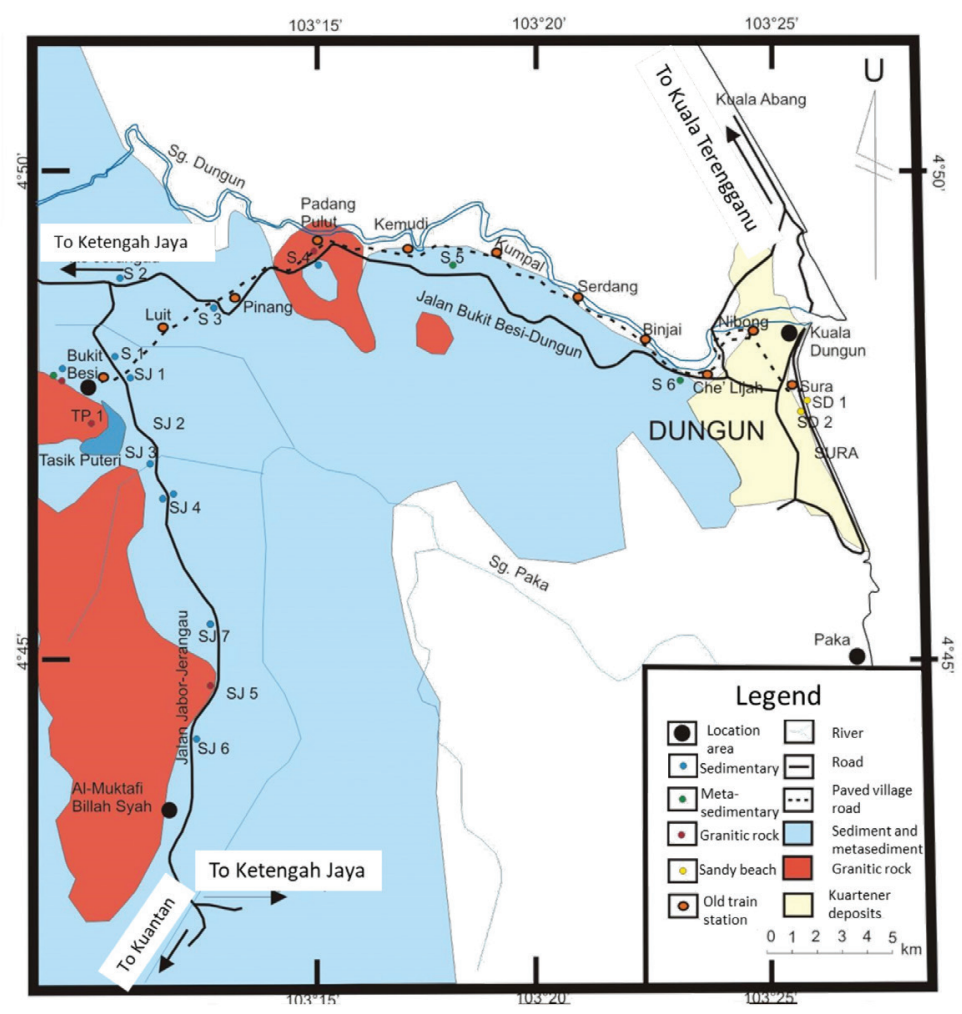

FIGURE 2. Geological Map of Bukit Besi - Dungun area

Methods of the study were conducted by field survey along Dungun to Bukit Besi road and Bukit Besi to Bandar Al - Mukhtafi Billah Shah as shown on Figure 3, observation and sample collection. Laboratory test includes XRD and petrographic analysis. Based on the observations that have been done, the area around Bukit Besi is dominated by shales. Shale in the area is characterized by generally white, soft and slightly weathered (Figure 3). This shale outcrops mostly have a clear bedding, strike and dip readings in the range of $264^{\circ} / 73^{\circ}$. Based on X-ray diffraction analysis, the mineral content present in the shale samples are tourmaline, hornblende and rutile.

Two localities of granitic rocks which are TP1 and SJ5 show outcrops of granite boulders with red-orange coloured soil (Figure 4). Based on the analysis of X-ray Diffraction (XRD), mineral present in the soil of granite are kaolinite and goethite. Kaolinite is a secondary mineral formed by the weathering of feldspar, whereas goethite is a secondary mineral iron ore. The presence of secondary mineral goethite is likely influenced by it is situated near the area of iron ore mines or due to the end result of weathering (Figure 4).

There are also two localities that showed the presence of carbonaceous phyllite at S5 and S6 localities (Figure 5). Mining area showed the presence of a variety of lithologies, including shale, granite, quartzite, and limestone (limestone however is not found during the mapping). Granite rocks in the mining area generally consist of two types, namely the coarse-grained granite and fine-grained granite (Chong 1970). Mineral composition in both type of granites are similar which show the presence of quartz, feldspar and plagioclase; biotite and muscovite occur as accessory

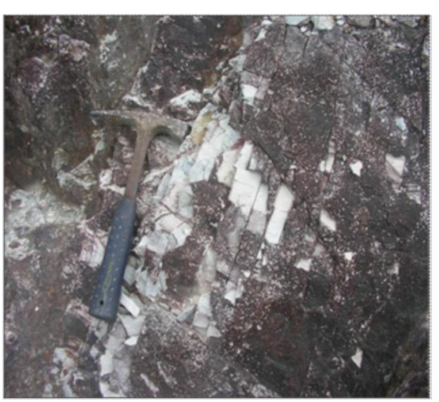

(a)

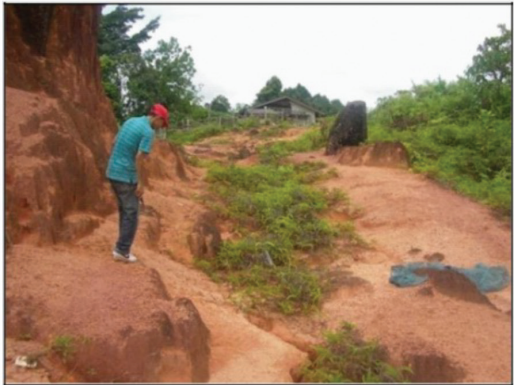

(b)

FIGURE 3. (a) Shale in the study area and (b) granite outcrop at TP1 


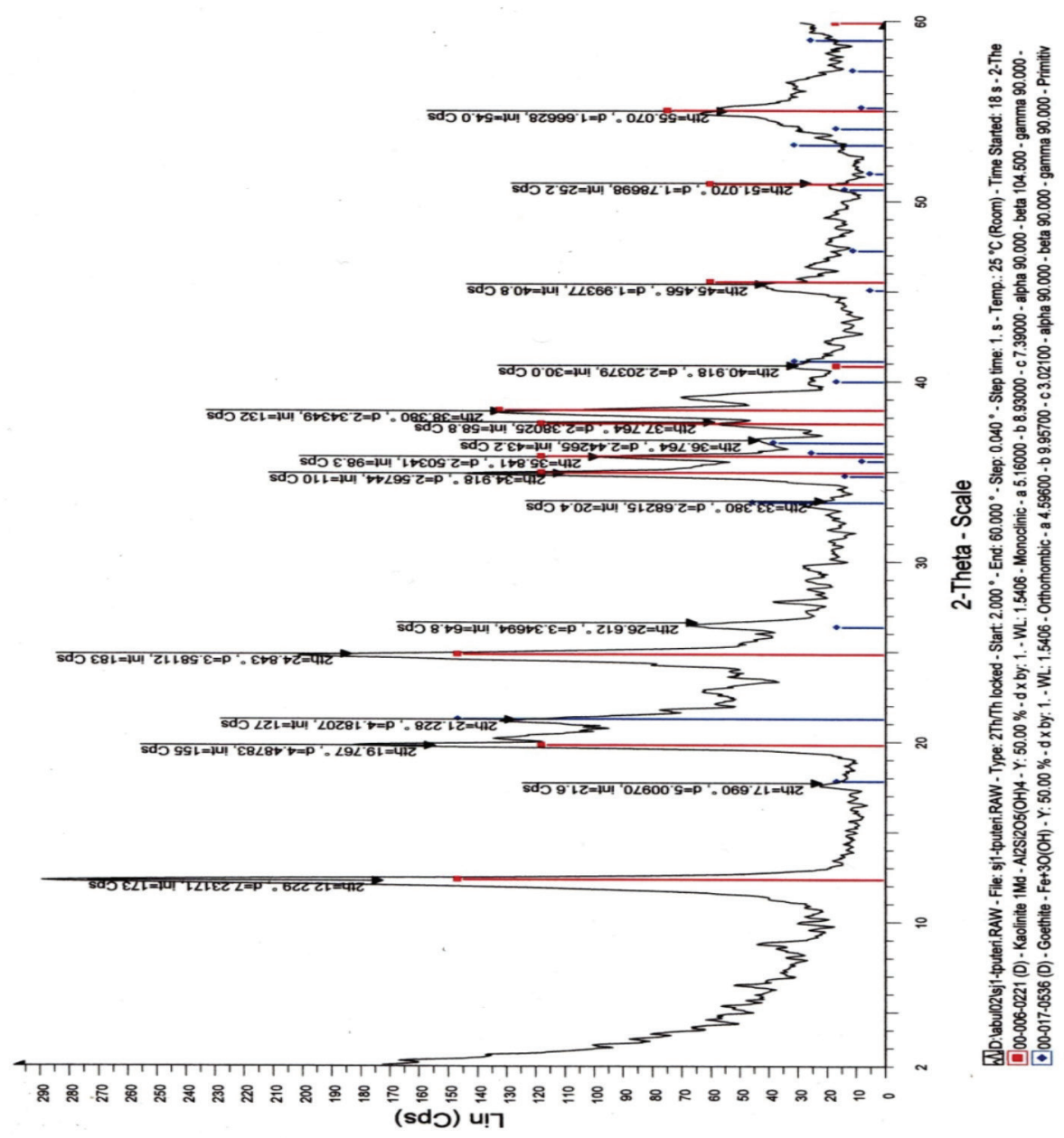

FIGURE 4. XRD result showed mineral present in the soil of granite are kaolinite and goethite

minerals (Ghani et al. 2018). Shale was the most dominant rock as iron are mostly occurred in this rock. Major iron ore minerals that are commonly found are magnetite, haematite and goethite (Abdul Rahman 1996). Petrographic sample has been analysed from an in-situ marble in the mining area as shown on Figure 5.

\section{HISTORY OF IRON ORE FORMATION}

Bukit Besi is located in the area marked by inconsistent contact between igneous and sedimentary rocks. Lithologies found in this area are numerous, including igneous, sedimentary and metamorphic. Shale rock dominated the area, and is the most common rock containing iron ore. In addition, iron ore found in the area are also present in limestone skarn and granite (Chong 1970). Among other lithologies present here include quartzite and marble. Most of the rocks are low-grade metamorphism as a result of magma intrusion during Permian-Triassic age.

Mineralization process occurred in Bukit Besi is pyrometasomatisme. Pyrometasomatisme is the formation of contact-metamorphic mineral deposits at high temperatures by emanations issuing from the intrusive and involving replacement of enclosing rock with addition or subtraction of materials (American Geosciences Institute 2013). This explained the process of iron ore formation in this area occurred at high temperature degree. Ore deposits in Bukit Besi contain minerals such as magnetite, hematite, goethite, and maghemite (Figure 6).

There are also minerals associated with sulphide ores, such as pyrite, pyrrhotite, and chalcopyrite. These minerals are distributed uniformly and irregularly in the existing of ore bodies as replacements which is influenced by the existence of layering (Evans 1986). This includes the replacement of limestone skarn, mineral replacement in shale, lenses and pod-shaped body and mineral replacement in granite (Hill 1962). Figure 7 shows schematic diagram of iron mineralization in Bukit Besi.

\section{MINING HISTORY OF BUKIT BES}

'Bukit Besi' is a Malay term refering to iron hill, illustrates the wealth of iron ore in the area (MacDonald 1968; Panton 1958). There is a lack of scientific research on iron ore deposits in the area. Only in 1916, a team of researchers from Japan suggested that a detailed study should be done on the prospect of Bukit Besi. Studies by 


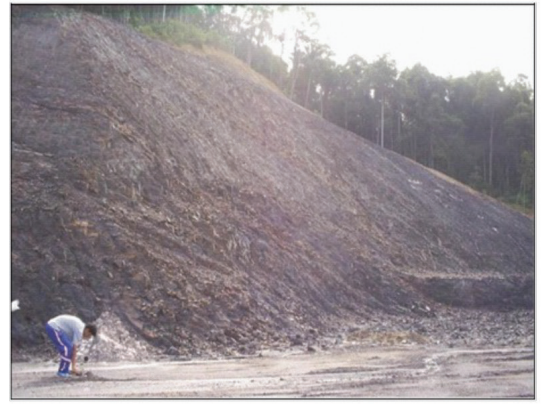

(a)

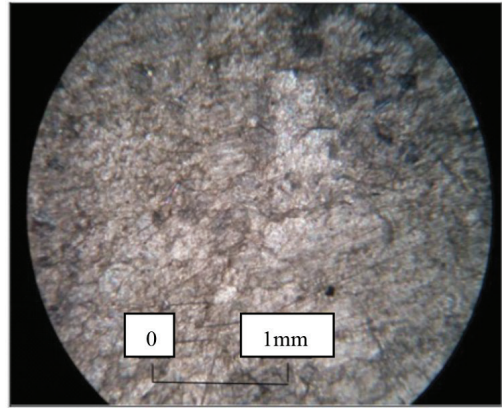

(b)

FIGURE 5. (a) Outcrop of carbonaceous phyllite and (b) Absence of dolomite in the petrographic section
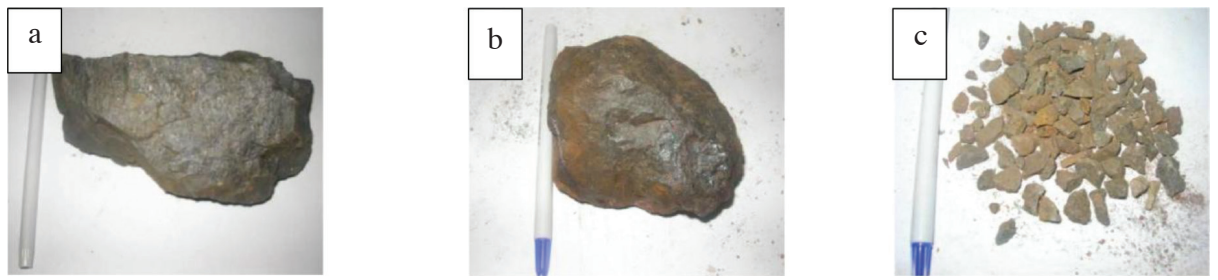

FIGURE 6. (a) Magnetite, (b) Hematite and (c) Goethite found in the iron ore

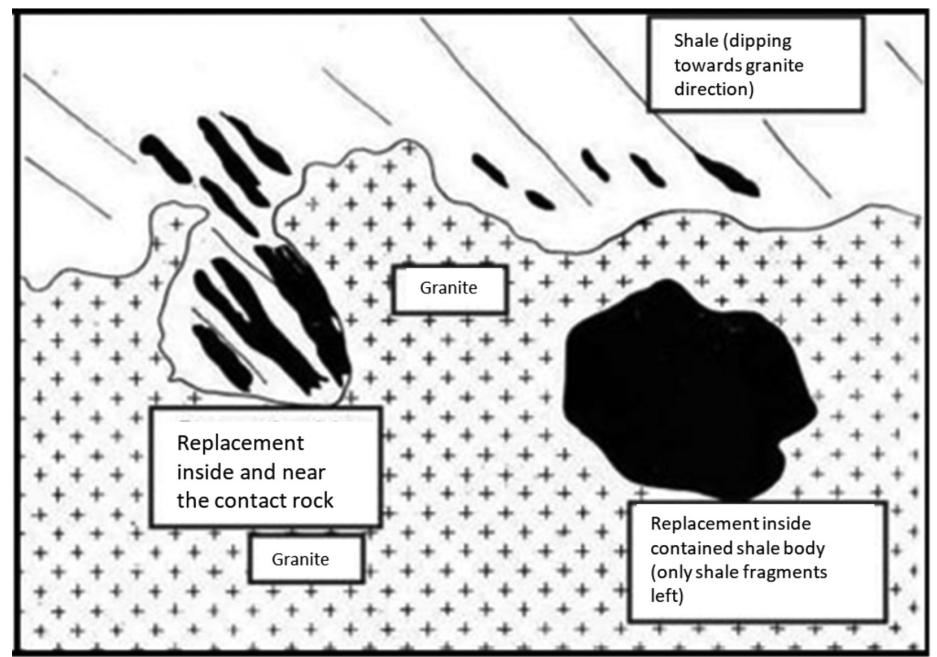

FIGURE 7. The pattern of ore replacement in Bukit Besi (modified from Hill 1962)

the Japanese researchers in 1916 found the Bukit Besi area contains abundant iron ore resources and are economical to run (Majallah Bulanan Malaya, 1957). In 1923, the state government finally issued a license to mine the ore to Kuhara Mining Company which later became known as Nippon Mining Company (NMC) . Ore bodies are divided into three areas, referred to as East zone, West, and Central (Gobbett \& Tdjia 1973). The three blocks contain an estimated 9 million tons of ore with an average of 54.40 percent Fe (Hill 1962).

In 1927, Kuhara (Nippon) Mining Company has signed a contract to supply iron ore to the Yawata Steel Works in Japan. Light rail construction is carried out in 1928 (Hill 1962). The railway consists of Bukit Besi station, Luit station, Pinang station, Padang Pulut station, Kemudi station, Kumpal station, Serdang station, Binjai station, Che' Lijah station, Nibong station and Sura station (Figure 8).

Until 1942, most of the ore production of Malaya are from Bukit Besi Mine (Chand 1966). No ore production was recorded between the years 1942 and 1948. Almost the entire production of Peninsular Malaysia ore between 1951 and 1957 are from the Bukit Besi Mine. Several factors have caused an abrupt change in Bukit Besi iron ore production. World War 2, restriction on the iron ore exports especially on prevention of shipping large quantities of ore led to the accumulation of a large ore stockpile in two shipping centers, Nibong and Sura (Hill 1962). As a result, 


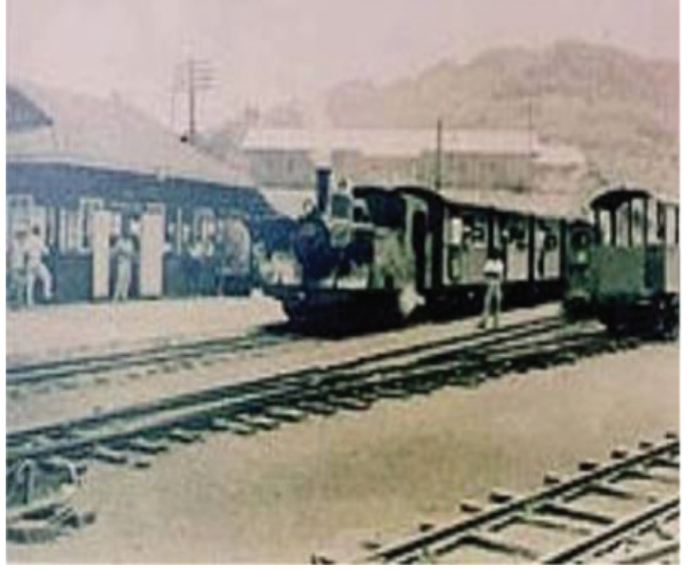

Source: Bukit Besi Gallery

FIGURE 8. The panorama at the Bukit Besi railway station. The figure shows a view of the Bukit Besi mining area as background

two ore smelter plant were built to overcome the problems. The plants can produce more than 3,500 tons of iron until the end of May 1945.

During British occupation they changed NMC into the Eastern Mining and Metals Company Limited (EMMCO). In 1973 EMMCO had halted mining operations at Bukit Besi due to several factors among which are short supply of iron ore resources, high management expenses and tax. However, due to the high prices, small scale iron ore mining is still being performed by local companies.

\section{IRON ORE PROCESSING}

The first impression towards Bukit Besi Mine would be its' gigantic iron ore mining complex. It reflects large-scale iron ore production during its' golden era in comparison to the current mining works. Iron ore processing involves crushing, screening, separation, heating and the production of steel. Rock mass of bulk iron ores are broken down into smaller rocks with crushing machine. The object is also rotated in a blender so that the smaller size of the rock mass is produced. The Ore bodies that have been crushed are then going through the screening process. After sorting process through magnetic separation methods, the ores will then achieve required standard size to go through the next process. Rock mass which does not exceed the standard size will be rotated back and screened until standard size is obtained. The heating process of iron ore and steel making is done in iron manufacturing plant. Currently, iron ore mined from Bukit Besi that has passed the screening process is sent to manufacturing plant in Gebeng, Kuantan. By comparing the ore processing at the mine in operation and the remains of the mine, it can be interpreted that the scale of production of iron ore between the two is far different as shown in Figure 9.

\section{REMNANTS OF HISTORIC BUILDINGS IN BUKIT BESI}

Bukit Besi has many remains of buildings and mining sites of interest (Lembaga Kemajuan Tanah Terengganu Tengah 2009). The slow conservation process has caused most of the artifacts and mining machinery made of steel were melted for other uses. Therefore, what remains now are only the remnant of relic sites and historic buildings that can still be visited and surveyed.

Iron Ore Crushing Site and Tin Crusher Plant Crusher crushing plant is a site rocks containing iron ore brought from the nearby mines. There are two types of ore at the mine in Bukit Besi, namely iron ore plant and tin plant (Figure 10). They have similar function which are crushing block size ore bodies into smaller size. Usually crushing process is followed by the process of cleaning and washing using water to separate the impurities in the ore. The crushed rocks are then transported to storage building called opal by using a wagon through a tunnel.

Storage Building (Opal) Opal in Bukit Besi refers to a large building that acts as a temporary storage of rock containing iron ore processed from the site of Tin Plant and Crusher Plant (Figure 11). The building is also known as a stock pile and is located near the crushing plant and Tin Plant. It has an interesting and unique building. In one of the rooms in the building, the roof is made up of stacks

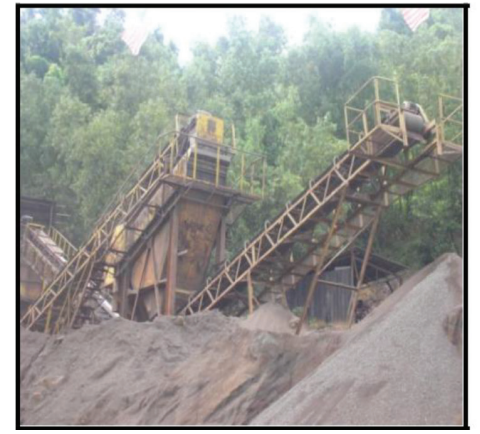

(a)

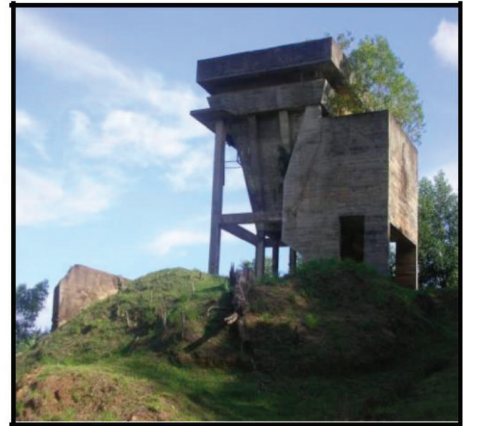

(b)

FIGURE 9. Comparison of crusher used in different mining era, the size was vastly different,

(a) crusher used by the current mining operation and (b) the old crusher remnant 


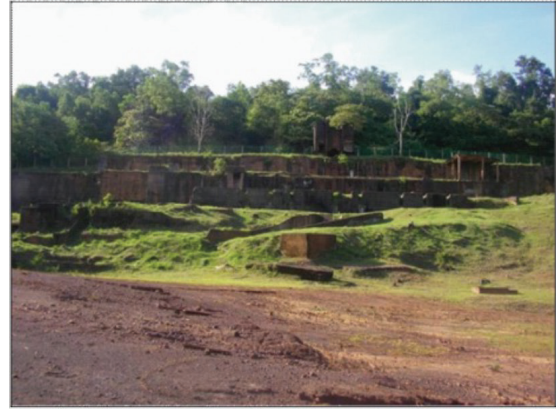

(a)

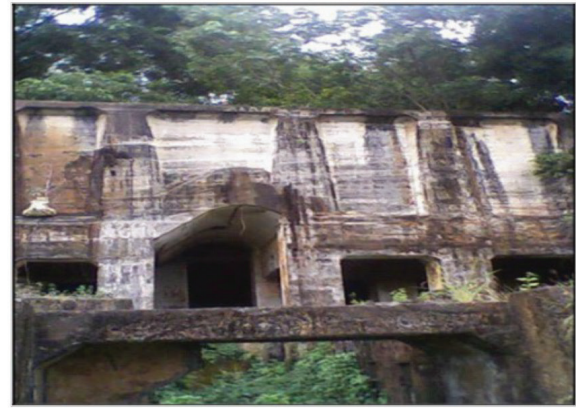

(b)

FIGURE 10. (a) iron ore plant and (b) tin plant site

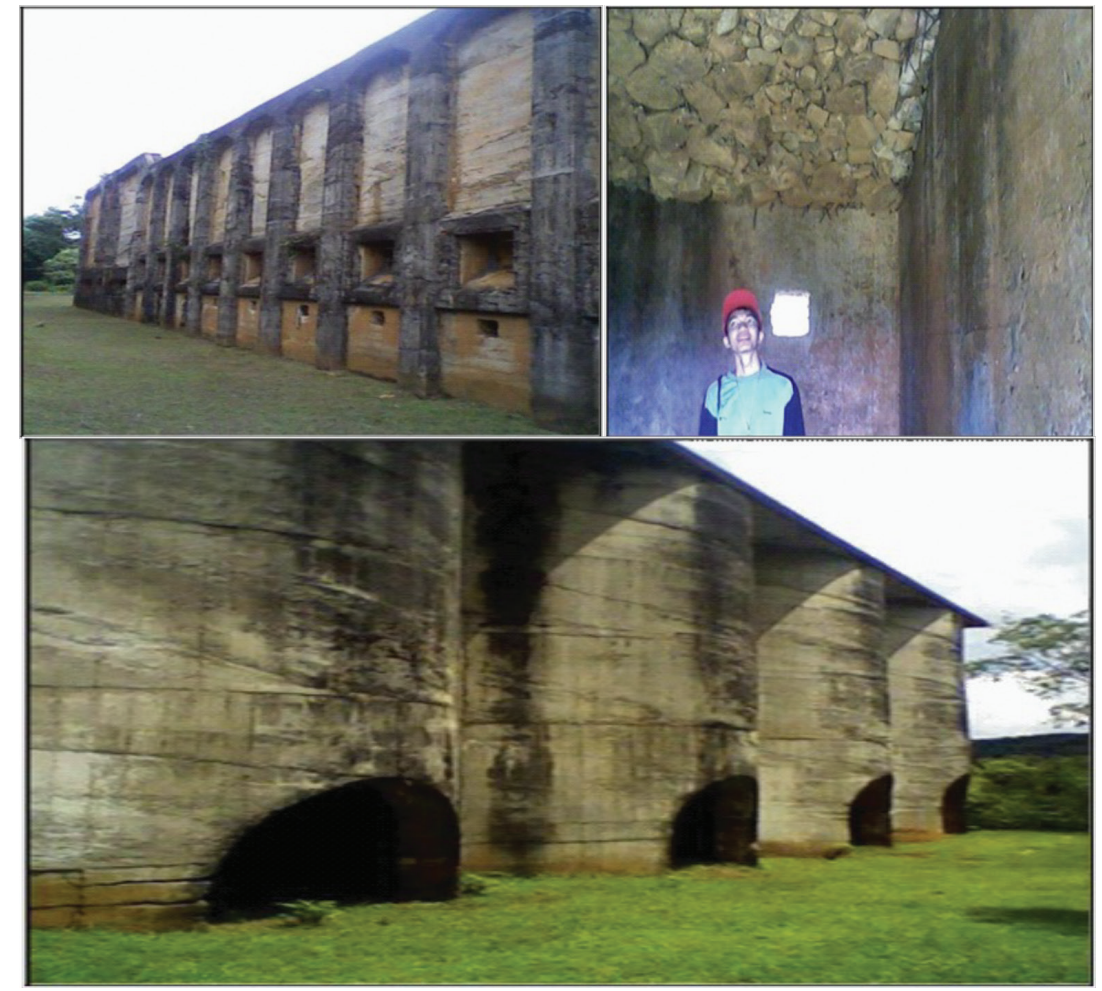

FIGURE 11. Opal building that serves as a temporary storage of crushed rocks from previous site and maintain the quality of the ore that is stored here before transported

of small blocks of various rock types. This is believed intended to cool the room temperature and maintain the quality of the ore that is stored here.

In addition to the rectangular Opal, there is another opal that has different structural building but having equivalent functionality which located in the same area and used for the storage of iron ore before it was sent to the ports at Nibong and Sura as shown at Figure 11. The building shows variations from the previous opal building through a larger shape, height, and a set of vertical tunnelshaped cylinder with hollow at the bottom.

Chimney Chimney is a high building and serves as a site to process ore into gold bar. It has been built since 1942, but the British ordered the construction of a second Chimney at higher level than previous one.

\section{PROPOSED GEOTOURISM MAP}

Preparation of a geotourism map as a guide of directions for each mining artifacts of interest is essential for the convenience and reference for visitors visiting Bukit Besi (Figure 12). Bukit Besi is a unique area where mining artifacts are divided into different complexes that constructed based on its form and function. This map serves as an initial overview for the visitors before touring Bukit Besi.

\section{CONCLUDING REMARKS}

Though its heyday has passed, Bukit Besi has left an invaluable history to be remembered by the next generation and as potential tourist attraction spot generated based 


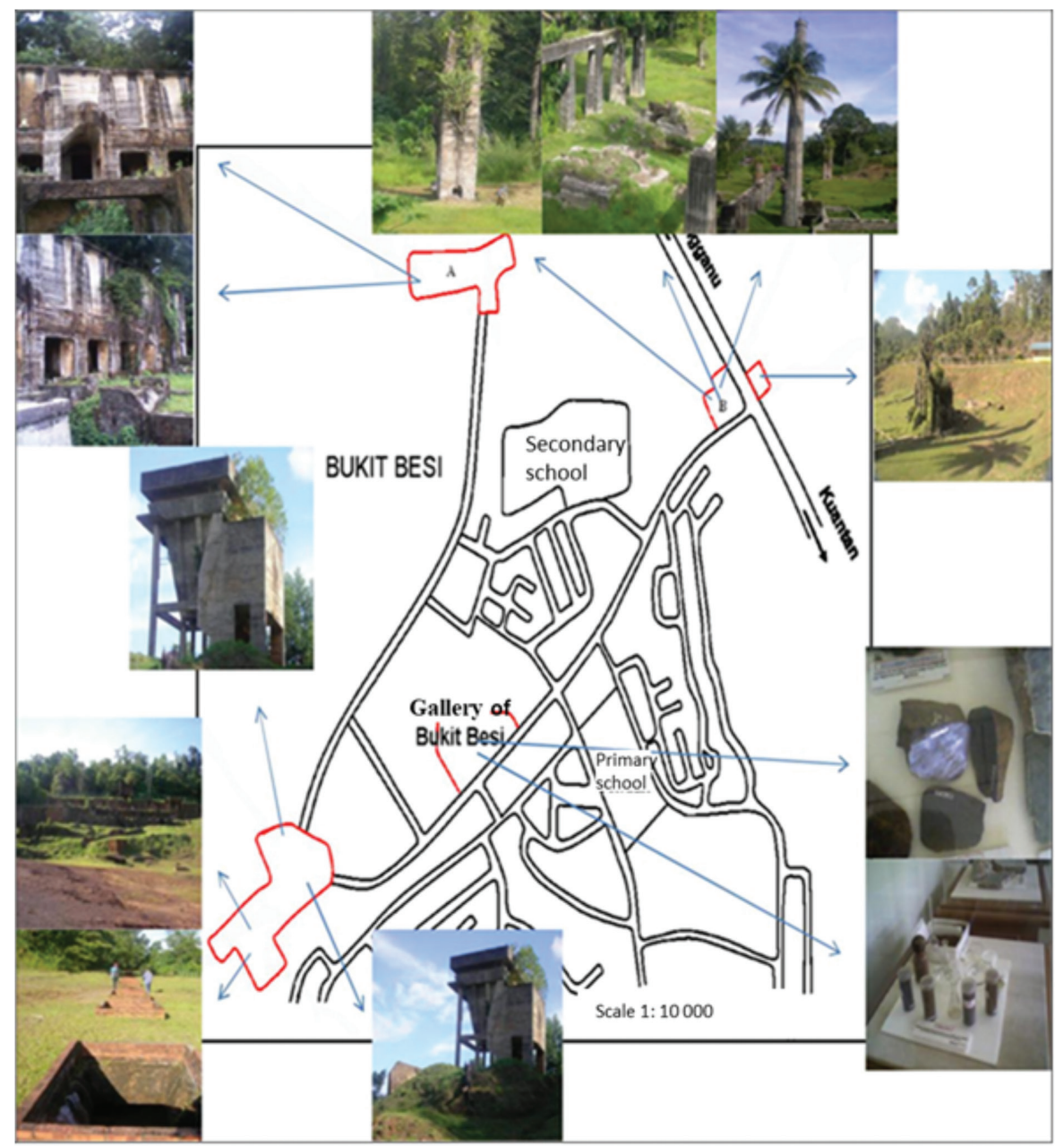

FIGURE 12. Geotourism map of Bukit Besi Mine indicating the location of the remnants of mining artifacts (quoted and adapted from KETENGAH webpage)

on geotourism concept. Geotourism, such as ecotourism is a package of assets for tourism activities, particularly natural geological landscape. Tourism geology is a body of knowledge related to geological exploration and generation of natural resources as natural assets for touristic development. An area that has the potential to be developed as tourist spots will be given additional information from various aspects of geology, as a new source of tourism, to increase the interest of tourists to visit the area. As an ex mining site and the availability of a lot of interesting mining artifacts, Bukit Besi can be developed into a new tourist attraction. The process of formation of ore and lithological characteristics of the area can be used as an additional information and useful knowledge for the tourists to gain. This study is only an introduction to the framework of geotourism development in Bukit Besi. Further research needs to be done especially in detail characterisation of Bukit Besi geosite in order for this area to be declared as Geopark.

\section{ACKNOWLEDGEMENTS}

Authors would like to express sincere gratitude to KETENGAH for their endless support and guidance in this research.

\section{REFERENCES}

American Geosciences Institute, 2013. https://www. americangeosciences.org/word/pyrometasomatism.

Anuar Yusof. 1985. Mineral Clearance, Jilid III, Syit 49 - Bukit Besi, Terengganu. Geological Survey Malaysia. Ipoh. Geological Survey Headquarters.

Anuar Yusof. 1983. Mineral Clearance, Jilid II, Syit 49 - Bukit Besi, Terengganu. Geological Survey Malaysia. Ipoh. Geological Survey Headquarters.

Bean, J.H. \& Hill, J.H. 1969. The Iron-Ore Deposits of West Malaysia. Economic Bulletin. Ipoh: Geological Survey of West Malaysia.

Burton, C.K. 1973. Mesozoic. In Geology of the Malay Peninsula, edited by Gobbett, D.J. \& Hutchison, C.S. New York: John Wiley. pp. 97-124.

Chand, F. 1966. Sheet 61-Terengganu, Vol.3. Geological Survey Malaysia. Ipoh: Geological Survey Headquarters.

Chong, N.H. 1970. The geology and mineralization of Batu Tiga Old Pit, Bukit Besi, Terengganu. BSc Thesis, Jabatan Geologi Universiti Malaya (Unpublished).

Duncan, J.H. 1959. Comments on Bukit Besi Iron Mine, Dungun, Terengganu. Geological Survey, Federation of Malaysia.

Evans, A.M. 1986. Pengantar Geologi Bijih. Trans. by Wan Fuad Wan Hassan. Kuala Lumpur: Dewan Bahasa dan Pustaka. 
Ghani, A.A., Muzammil Shahjamal, Ng, T.F., Noer El Hidayah Ismail, Mohamad Tarmizi, M.Z., Nur Islami, Quek, L.X., Ahmad Farid Abu Bakar, Meor Hakif Amir Hassan, Jasmi Hafiz Abdul Aziz \& Amira Fahira Masor. 2018. Ce Anomaly in I-type granitic soil from Kuantan, Peninsular Malaysia: Retention of zircon in weathering product. Sains Malaysiana 48(2): 309-315.

Gobbett, D.J.\& Tdjia, H.D. 1973. Tectonic history. In Geology of the Malay Peninsula, edited by Gobbett, D.J. \& Hutchison, C.S. New York: John Wiley. pp. 61-87.

Hill, J.H. 1962. Geology of the Bukit Besi Ore Deposits. Ipoh: Geological Survey of West Malaysia.

Ibrahim Komoo \& Hamzah Mohamad. 1993. Geopelancongan: Pendekatan berterusan ke arah pemulihan khazanah geologi. In Warisan Geologi Malaysia, edited by Ibrahim Komoo, Mohd Shafeea Leman, Kadderi Md Desa dan Ibrahim Abdulah. Bangi: Institut Alam Sekitar (LESTARI) UKM. pp. 47-71.

Jabatan Mineral dan Geosains Malaysia. 2004. Peta Geologi Negeri Terengganu. Scale 1:250,000.

Jabatan Pemetaan Negara. 1969. Peta Bukit Besi. Siri L7010. cetakan 4-DNMM. Sheet 49. Scale 1:63,360.

Jabatan Pemetaan Negara. 1968. Peta Kuala Dungun. Siri L7010. cetakan 4- DNMM. Sheet 50 dan 51. Scale 1:63,360.

Kadderi, M.D. 2000. Tourism Geosciences: A New Subdicipline in Geoscience Education. Proceedings of Annual Geological Conference 2000. Penang.

Kadderi Md. Desa. 1995. Geotourism: Geological potential for developing tourism industry in Malaysia (in Malay). Prosiding Seminar Geologi Abad Ke-21: Cabaran dan Peluang. Bangi.pp. 175-180.
Lembaga Kemajuan Tanah Terengganu Tengah, 2009. Peta Artifak Bukit Besi dan Foto. www.ketengah.gov.my.

MacDonald, S. 1968. Geology and Mineral Resources of North Kelantan and North Terengganu. Geological Survey West Malaysia District Memoir No. 10.

Majallah Bulanan Malaya. 1957. Arkib Negara, Kuala Lumpur. Jil. 2 Bil. 11: 6-10.

Mohd Shafeea Leman \& Ibrahim Komoo. 2004. Warisan Geologi Malaysia: Kerangka Teori dan Penilaian Geowarisan, Bangi: Institut Alam Sekitar (LESTARI) UKM. pp. 258.

Panton, W.P. 1958. Reconnaissance Soil Survey of Terengganu. Kuala Lumpur.

Centre of Earth Sciences and Enviroment

Faculty of Science and Technology

Universiti Kebangsaan Malaysia

43600 UKM Bangi, Selangor Darul Ehsan

Malaysia

*Corresponding author; email: marilah@ukm.edu.my

Received: 14 April 2019

Accepted: 15 August 2019 